\title{
L-Lactide polymerization by calix[4]arene-titanium (IV) complex using conventional heating and microwave irradiation
}

\author{
Marco Frediani, ${ }^{1 *}$ David Sémeril, ${ }^{2}$ Dominique Matt, ${ }^{2}$ Fabio Rizzolo, ${ }^{13}$ Anna Maria \\ Papini, ${ }^{13}$ Piero Frediani, ${ }^{1}$ Luca Rosi, ${ }^{1}$ Marco Santella, ${ }^{1}$ Guido Giachi ${ }^{1}$
}

$1^{1 *}$ Department of Organic Chemistry, University of Florence, Via della Lastruccia 13, 50019 Sesto Fiorentino, Italy; fax: +39 (0)55 4573531; e-mail: marco.frediani@unifi.it. ${ }^{2}$ Laboratoire de Chimie Inorganique Moléculaire et Catalyse, Institut de Chimie UMR 7177 CNRS, Université de Strasbourg, 1 rue Blaise Pascal, F-67008 Strasbourg cedex, France.

${ }^{3}$ Laboratory of Peptide \& Protein Chemistry \& Biology, Polo Scientifico e Tecnologico, University of Florence, 50019 Sesto Fiorentino, Italy.

(Received: 24 August, 2009; published: 24 February, 2010)

\begin{abstract}
Since the first contributions by Gedye and Giguere in 1986, growing attention has been registered on the use of microwave heating in organic synthesis. However still many aspects need to be clarified especially about the so called "microwave effect" and the possible degradation phenomena that may be recognized during polymer synthesis. In this work the complex cone-25,27dipropyloxy-26,28-dioxo-calix[4]arene titanium (IV) dichloride (1) has been tested for the ring opening polymerization of $L$-lactide, comparing the effect of conventional heating with a possible microwave assisted strategy. The polymers obtained were fully characterized (NMR, IR, HPLC-SEC, DSC, MALDI-TOF and WAXD analysis). As expected the use of microwave irradiation induced an increase of the polymerization rate. On the other side the use of microwaves resulted in a slight loss of the control over molecular weight and molecular weight distribution if compared with a conventional thermal treatment.
\end{abstract}

\section{Introduction}

Ring opening polymerization (ROP) of optically active cyclic monomers is the method of choice for the synthesis of polymers with high control on molecular weight and low racemization level. The efficiency of tin compounds (i.e. $\left.\mathrm{Sn}(\mathrm{Oct})_{2}\right)$ in the ROP of $L$ lactide (LLA) is well documented in the literature [1]. However, due to the toxicity of organotin derivatives, such complexes cannot be used for the synthesis of polylactides finding medical applications. In this context, the development of new catalysts based on non toxic oxophilic metals still represents an important objective [2]. In particular, the development of catalytic systems involving group IV metal complexes is currently attracting much attention. Due to the variety of structures available with these metals, it may be anticipated that fine-tuning of the corresponding complexes will allow elaboration of new polymers with well-defined properties [3].

Generic calix[4]arenes are readily available macrocyclic molecules made of four phenol units linked via methylene bridges. The presence of four oxygen atoms at the lower rim of these conical molecules provides an interesting platform for the synthesis of poly(phenoxy) metal complexes. Recently we have reported on a 
calix[4]arene titanium complex that was found active in the ROP of lactides [4]. As a matter of fact calix[4]arene-derived ligands not only display a high structural versatility, but may also confer a high thermal stability to the corresponding complexes. Furthermore, some of them possess high human compatibility [5].

Since the first contributions by Gedye [6] and Giguere [7] in 1986, a growing attention has been registered on the use of microwave heating in organic synthesis. However still many aspects need to be clarified especially about the so called "microwave effect" and the possible degradation phenomena that may be recognized during polymer synthesis $[8,9]$. Recently much attention has been focused on the synthesis of poly(lactide) [10].

In the present work we describe for the first time the use of cone-25,27-dipropyloxy26,28-dioxo-calix[4]arene titanium (IV) dichloride (1) (Scheme 1) in the ROP of Llactide as a comparison between the effects on the polymerization under standard thermal treatment and microwave irradiation.

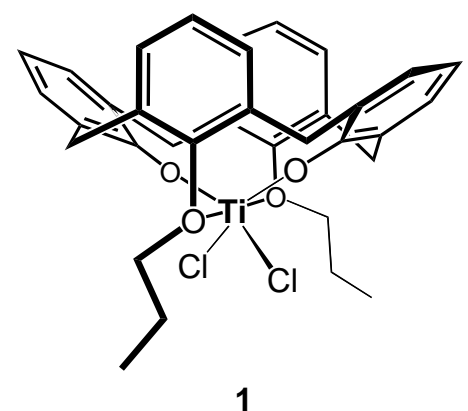

Scheme 1. 25,27-Dipropyloxy-26,28-dioxocalix[4]arene titanium (IV) dichloride.

\section{Results and discussion}

First of all the thermal stability of the catalyst was tested with TGA analysis, revealing that no decomposition of 1 occurred at temperatures below $230^{\circ} \mathrm{C}$. The high thermal stability of the complex may be attributed to the presence of the two propylsubstituted oxygen atoms able to stabilize the metal center through coordination [4, 11]. This property combined with the electron-deficient character of the titanium atom, makes 1 a potential precatalyst for ROP of $L$-lactide (Scheme 2). The catalytic runs were carried out under solvent-free conditions either using conventional heating or microwave irradiation. All analytical investigations (HPLC-SEC [12], DSC [13], NMR [14], MALDI-TOF [15] and WAXD [16]) were consistent with the formation of PLLA polymers. The MALDI-TOF spectra revealed the occurrence of transesterification during polymerization.

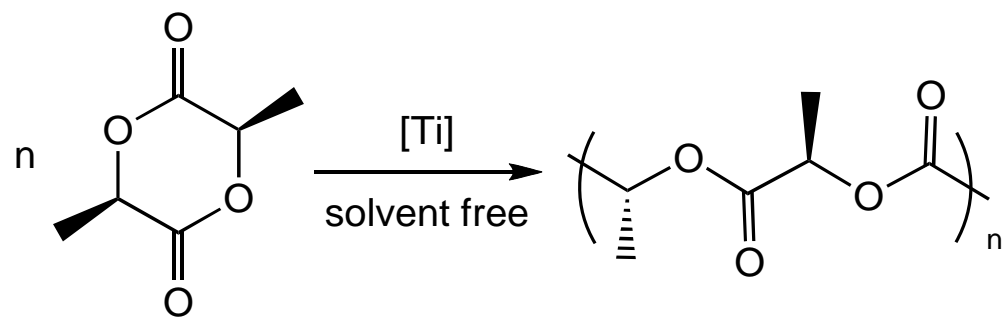

Scheme 2. Ring opening polymerization (ROP) of $L$-lactide. 


\section{Thermal heating}

Two series of polymerization reactions using thermal heating were carried out. Both series were performed using an oil bath at $130{ }^{\circ} \mathrm{C}$ (Table 1). We first studied the influence of the monomer/catalyst ratio ([LA]/[Ti]) in experiments carried over $3 \mathrm{~h}$ (Table 1, entries 1-5 and Figure 1).

Tab. 1. Thermal-assisted polymerization of $L$-lactide using complex 1.

\begin{tabular}{cccccccc}
\hline entry & $\begin{array}{c}{[\mathrm{LA}] /[\mathrm{Ti}]} \\
\text { ratio }\end{array}$ & $\begin{array}{c}\text { time } \\
(\mathrm{min})\end{array}$ & $\begin{array}{c}\text { conversion } \\
(\%)\end{array}$ & activity $^{\mathrm{b}}$ & $\begin{array}{c}M_{\mathrm{w}}{ }^{\mathrm{c}} \\
\left(\mathrm{g} \cdot \mathrm{mol}^{-1}\right)\end{array}$ & $\begin{array}{c}M_{\mathrm{n}}{ }^{\mathrm{d}} \\
\left(\mathrm{g} \cdot \mathrm{mol}^{-1}\right)\end{array}$ & MWD $^{\mathrm{e}}$ \\
\hline 1 & 1995 & 180 & 48 & 45.9 & 30300 & 24600 & 1.2 \\
2 & 1000 & 180 & 74 & 35.8 & 26600 & 21300 & 1.2 \\
3 & 498 & 180 & $>99$ & 24.9 & 30000 & 23800 & 1.3 \\
4 & 199 & 180 & 97 & 9.3 & 29800 & 25300 & 1.2 \\
5 & 100 & 180 & $>99$ & 4.8 & 18800 & 14000 & 1.3 \\
6 & 200 & 120 & 93 & 13.4 & 28700 & 22800 & 1.3 \\
7 & 199 & 90 & 72 & 13.9 & 22000 & 17900 & 1.2 \\
8 & 202 & 60 & 60 & 17.2 & 14200 & 12000 & 1.2 \\
9 & 200 & 30 & 12 & 7.0 & n.d. & n.d. & n.d. \\
\hline
\end{tabular}

a) determined by ${ }^{1} \mathrm{H}$ NMR

b) $\mathrm{kg}(\mathrm{PLLA}) \cdot \mathrm{mol}(\mathrm{cat})^{-1} \cdot \mathrm{h}^{-1}$

c) number average molar mass measured by HPLC-SEC

d) weight average molar mass measured by HPLC-SEC

e) molecular weight distribution

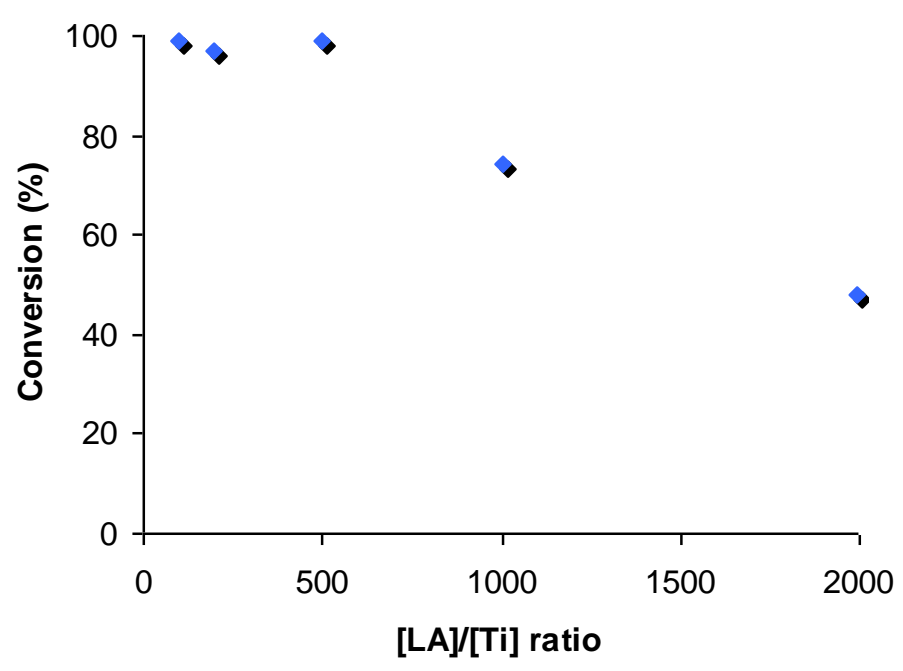

Fig. 1. Variation of the conversion as a function of the monomer/catalyst ratio.

Full conversion was observed for [LA]/[Ti] ratios lower than 500. For higher [LA]/[Ti] ratios, the conversion decreased with a linear dependence. The conversion reached $48 \%$ when applying a [LA]/[Ti] ratio of 1995 . In this latter case the highest activity was observed (45.9 $\mathrm{kg}(\mathrm{PLLA}) \cdot \mathrm{mol}(\mathbf{1})^{-1} \cdot \mathrm{h}^{-1}$; Table 1, entry 1). As expected, the 
molecular weight increased when the $[\mathrm{LA}] /[\mathrm{Ti}]$ ratio increased. For example, $M_{\mathrm{w}}$ passed from 18800 to $30300 \mathrm{~g} \cdot \mathrm{mol}^{-1}$ when going from a [LA]/[Ti] ratio of 100 to a ratio of 1995 (Table 1, entries 1 and 5). Despite concomitant transesterification during polymerization, the formation of polylactide was well controlled, the molar mass distribution indexes remaining in the restricted range of 1.2-1.3.

For the second series of runs, we studied the influence of the time on the conversion. These experiments were performed using a [LA]/[Ti] ratio of 200 (Table 1, entries 4 and 6-9). Under these conditions full conversion was observed after $3 \mathrm{~h}$. We found that a conversion of $93 \%$ required only $2 \mathrm{~h}$ of reaction time. This corresponded to an activity of $13.4 \mathrm{~kg}(\mathrm{PLLA}) \cdot \mathrm{mol}(\mathrm{cat})^{-1} \cdot \mathrm{h}^{-1}$ (Table 1 , entry 6$)$. The plot of the conversion as a function of time is shown in Figure 2. The corresponding ${ }^{1} \mathrm{H}$ NMR spectra show in each case two characteristic quartets, one for the monomer $(\delta=5.03 \mathrm{ppm})$, and another for the polymer (ranging from $\delta=5.13$ to $5.18 \mathrm{ppm}$ ) [14].

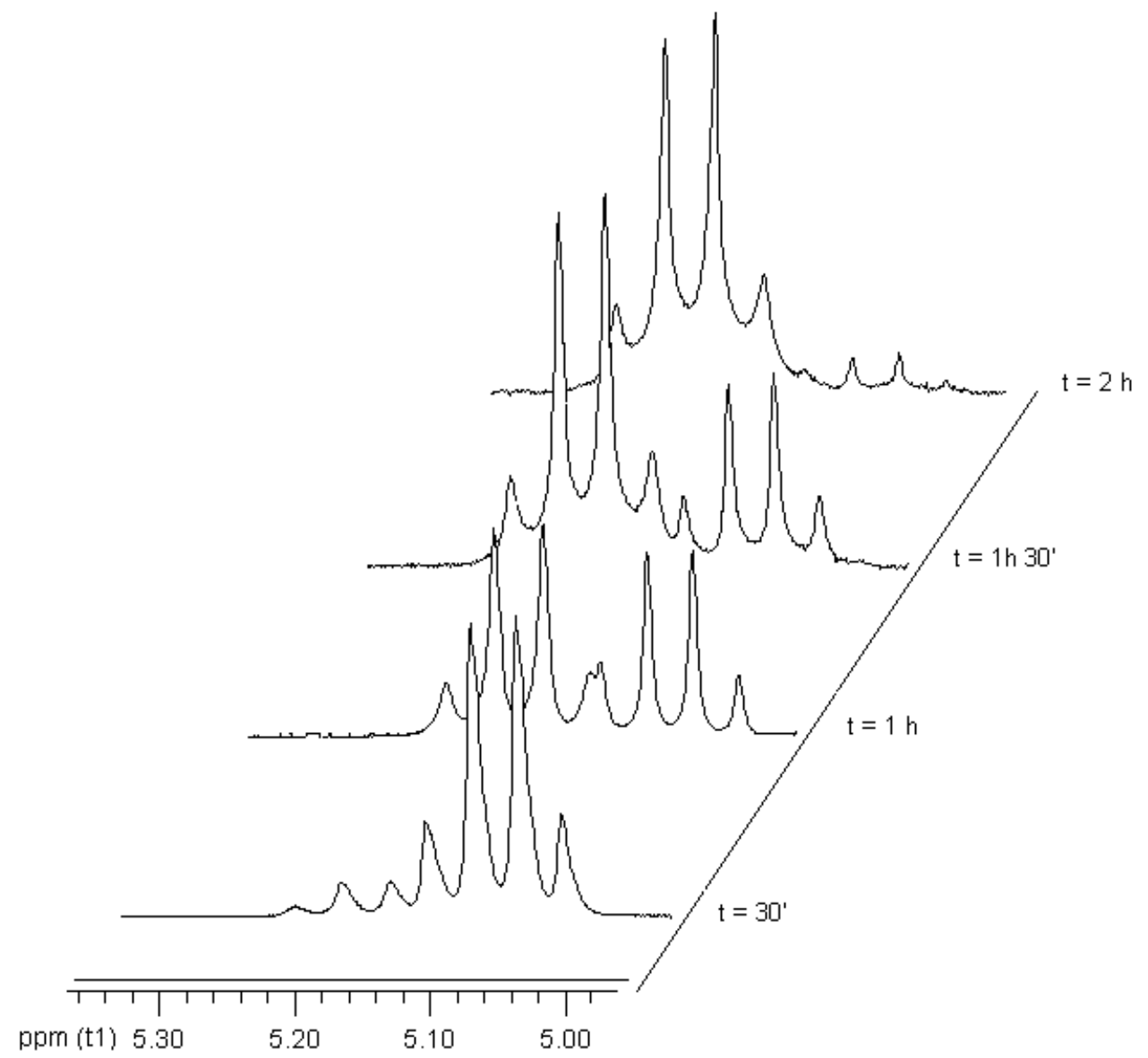

Fig. 2. Variation of the conversion as a function of time.

\section{Microwave assisted strategy (MW)}

Although the use of microwaves energy is well documented in the literature, only few examples of ROP using this technique were reported. The use of solvent-free conditions renders the microwave irradiation strategy slightly more delicate, leading to possible degradation. For the following polymerizations, we used a CEM Discover S-Class setting with an output power of $200 \mathrm{~W}$. The reaction temperature was monitored using an IR sensor. 
The runs were carried out using a [LA]/[Ti] ratio of 200 (Table 2). All analytical data (HPLC-SEC, NMR, DSC, MALDI-TOF and WAXD) of the polymer formed were typically those of PLLA. Under the experimental conditions used, an increase of the polymerization rate was observed with respect to the previous experiments. Thus, for example, a conversion of $95 \%$ was observed after 80 minutes, which corresponds to an activity of $22.1 \mathrm{~kg}(\mathrm{PLLA}) \cdot \mathrm{mol}(\mathrm{cat})^{-1} \cdot \mathrm{h}^{-1}$ (Table 2, entry 6). Longer polymerization times led to a partial decomposition of the organic compounds, as revealed by the appearance of a brown color and an acetaldehyde flavor. It is further noteworthy that for the polymers synthesized under microwave irradiation lower molecular weights and slightly higher molecular weight distributions were observed $\left(M_{\mathrm{w}}=18600 \mathrm{~g} \cdot \mathrm{mol}^{-1}\right.$; $M W D=1.4$; see Table 2, entry 5) than for those obtained by thermal heating.

Tab. 2. Microwave-assisted polymerization of $L$-lactide using complex 1.

\begin{tabular}{|c|c|c|c|c|c|c|c|}
\hline entry & $\begin{array}{c}{[\mathrm{LA}] /[\mathrm{Ti}]} \\
\text { ratio }\end{array}$ & $\begin{array}{l}\text { time } \\
(\min )\end{array}$ & $\begin{array}{c}\text { convertion }^{\mathrm{a}} \\
(\%)\end{array}$ & activity $^{b}$ & $\begin{array}{c}M_{\mathrm{w}}{ }^{\mathrm{c}} \\
\left(\mathrm{g} \cdot \mathrm{mol}^{-1}\right)\end{array}$ & $\begin{array}{c}M_{\mathrm{n}}^{\mathrm{d}} \\
\left(\mathrm{g} \cdot \mathrm{mol}^{-1}\right)\end{array}$ & $\mathrm{MWD}^{\mathrm{e}}$ \\
\hline 1 & 197 & 20 & 39 & 33.3 & 8100 & 5600 & 1.5 \\
\hline 2 & 200 & 40 & 85 & 36.9 & 14400 & 10600 & 1.4 \\
\hline 3 & 199 & 60 & 89 & 25.6 & 16400 & 11700 & 1.4 \\
\hline 4 & 200 & 30 & 74 & 42.4 & 13200 & 8800 & 1.5 \\
\hline 5 & 202 & 50 & 85 & 29.8 & 18600 & 13600 & 1.4 \\
\hline 6 & 216 & 80 & 95 & 22.1 & 17400 & 12000 & 1.4 \\
\hline
\end{tabular}

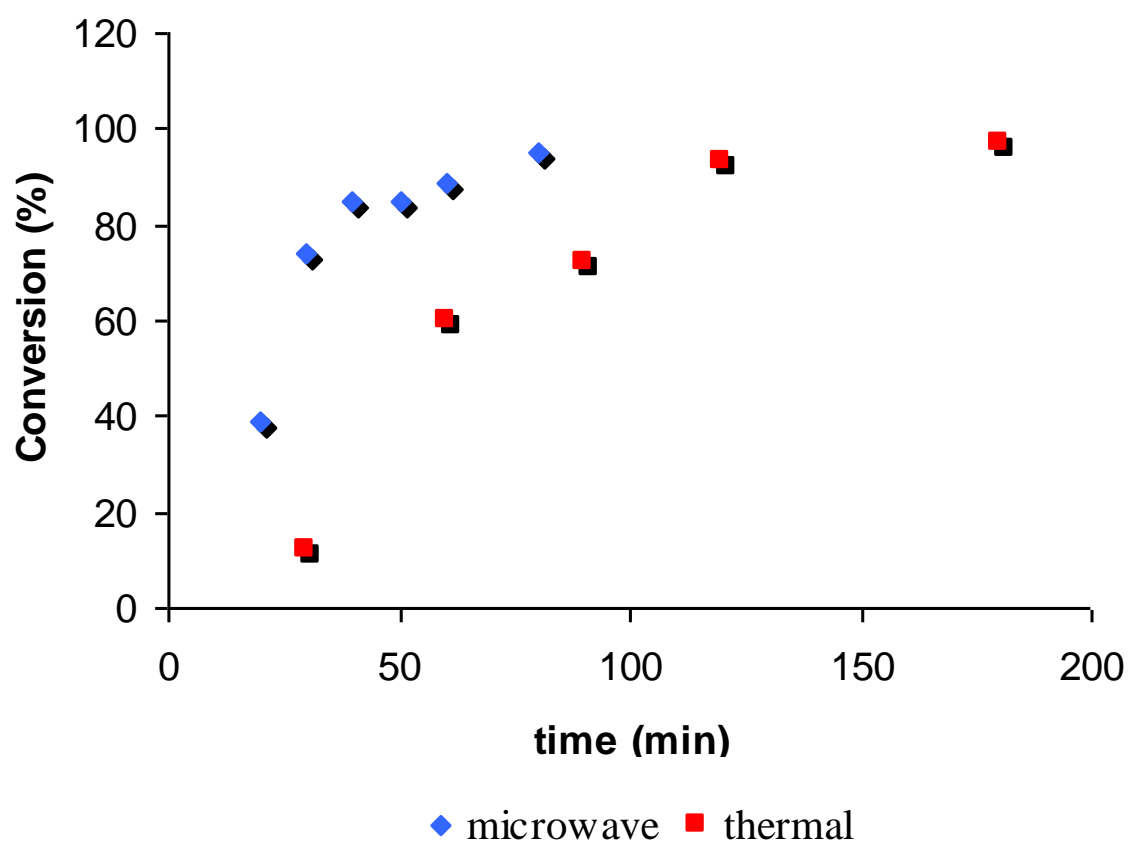

Fig. 3. Variation of the conversion as a function of time: comparison between thermal and microwave activating system. 
A comparison between thermal heating and microwave assisted process is reported in Figure 3. The plot of the conversion as a function of time clearly illustrates the increase of the polymerization rate when using the microwave irradiation: while full conversion was obtained after 180 minutes under thermal heating, only 80 minutes were needed for quasi full conversion under microwave irradiation. The study also showed that each heating mode required an activation period of a few minutes.

\section{Experimental part}

\section{General}

Manipulations of air- and/or water-sensitive compounds were performed under a nitrogen atmosphere using either standard Schlenk techniques or a MBraun glove box. L-lactide (L-LA) was obtained from Aldrich (>98\%), purified by repeated crystallization and dried under vacuum at $70-75{ }^{\circ} \mathrm{C}$ for $2-3 \mathrm{~h}$. The cone-25,27dipropyloxy-26,28-dioxo-calix[4]arene titanium (IV) dichloride (1) was prepared using a method reported in the literature [11].

\section{Polymerization experiments}

L-Lactide ( $L$-LA) polymerization was carried out by charging the desired amount of monomer and the appropriate amount of complex $\mathbf{1}$ into a vial. For these polymerizations, we preferred to carry out the reactions in vials instead of an autoclave, in order to compare directly the two heating systems. The vial was, either immersed into an oil bath at $130{ }^{\circ} \mathrm{C}$ or introduced automatically into a microwave oven (Discover S-Class System, CEM). A maximal power of $200 \mathrm{~W}$ was applied for the specified time while the temperature was monitored by an IR sensor positioned below the vial. In order to determine the conversion, the polymer was first analyzed by NMR, then recrystallized two or three times in $\mathrm{CHCl}_{3}$-hexane and dried in vacuum at $50{ }^{\circ} \mathrm{C}$ for $12 \mathrm{~h}$.

\section{Polymer characterization}

${ }^{1} \mathrm{H}$ NMR and ${ }^{13} \mathrm{C}$ NMR spectra were recorded on a Varian Mercury 400 apparatus using $\mathrm{CDCl}_{3}$ as solvent (solution $0.2 \mathrm{w} / \mathrm{w}$ ). Melting temperatures $\left(T_{\mathrm{m}}\right)$ of the polymers were determined by differential scanning calorimetry (DSC) with a Mettler-Toledo DSC 821e instrument equipped with an intracooler. The temperature scale was calibrated with an indium reference sample (melting transition of indium $156.1^{\circ} \mathrm{C}$ ). Aluminum pans were filled with $0.010 \mathrm{~g}$ of the polymer sample. The thermal history of the polymers was eliminated by heating the specimen at a rate of $20^{\circ} \mathrm{C} \cdot \mathrm{min}^{-1}$ to 200 ${ }^{\circ} \mathrm{C}$, keeping the sample at this temperature for one minute, then cooled at $20^{\circ} \mathrm{C} \cdot \mathrm{min}^{-1}$ to $0^{\circ} \mathrm{C}$. The second and third scans were then recorded from $0{ }^{\circ} \mathrm{C}$ to $200^{\circ} \mathrm{C}$. The molecular weight $\left(M_{\mathrm{w}}\right)$ and molecular weight distribution $\left(M_{\mathrm{w}} / M_{\mathrm{n}}\right)$ of the polymers were evaluated by size exclusion chromatography (HPLC-SEC) using a Perkin-Elmer type Series 2000 apparatus equipped with a Rheodyne 7010 injector [injection loop $200 \mu \mathrm{l}$, refraction index detector type LC-30 with two columns PL GEL (length: $30 \mathrm{~cm}$; diameter: $5 \mu \mathrm{m}$; Polymer Labs)]. The analyses were performed at $30^{\circ} \mathrm{C}$ using chloroform as solvent, with a flow rate of $1.0 \mathrm{~mL} \cdot \mathrm{min}^{-1}$ and standard polymethylmetacrylate (PMMA) as reference [12]. The samples were prepared by dissolving $0.005-0.006 \mathrm{~g}$ of polymer in $2 \mathrm{~mL}$ of chloroform (corresponding to ca. 3 $\mathrm{g} \cdot \mathrm{L}^{-1}$ ). The WAXD analyses were performed using a D8 Advance (Bruker) with a Solx solid state detector, using a Bragg-Brentano Geometry. All the samples were 
preventively heated at $120-130{ }^{\circ} \mathrm{C}$ for three days before analysis. The samples were exposed to a $\mathrm{Cu} \mathrm{K} \alpha \mathrm{X}$-ray source with a wave length $(\lambda)$ of $1.541 \AA$. The angle of incidence was varied from $4^{\circ}$ to $50^{\circ}$ by steps of $0.02 \theta$ for a period of $1.5 \mathrm{~s}$. The periodical distances $(d)$ of the main peaks were calculated according to Bragg's equation $(\lambda=2 d \sin \theta)$. MALDI-TOF analyses were carried out on a Ultraflex MALDI TOF/TOF from Bruker, with the following instrumental settings: in linear mode IS1 was set to $25 \mathrm{kV}$, IS2 to $23.70 \mathrm{kV}$ and delay time to $80 \mathrm{~ns}$. In reflection mode IS1 was set to $25 \mathrm{kV}$, IS2 to 21.50 and delay time was $20 \mathrm{~ns}$.

\section{Acknowledgements}

The authors are grateful to the University of Florence, the Italian MIUR (PRIN 2008), Regione Toscana and Ente Cassa di Risparmio di Firenze for financial support.

\section{References}

[1] Wu, J.; Yu, T.-L.; Chen, C.-T.; Lin, C.-C. Coord. Chem. Rev., 2006, 250, 602; Coulembier, O.; Degee, P.; Hedrick, J. L.; Duboi, P. Prog. Polym. Sci., 2006, 31, 723; Dechy-Cabaret, O.; Martin-Vaca, B.; Bourissou, D. Chem. Rev., 2004, 104, 6147; Nakano, K.; Kosaka, N.; Hiyama, T.; Nozaki, K. Dalton Trans., 2003, 21, 4039; O'Keefe, B. J.; Hillmyer, M. A.; Tolman, W. B. J. Chem. Soc., Dalton Trans., 2001, 2215; Garlotta, D. J. Polym. Environ., 2001, 9, 63.

[2] Dove, A. P.; Pratt, R. C.; Lohmeijer, B. G. G.; Culkin, D. A.; Hagberg, E. C.; Nyce, G. W.; Waymouth, R. M.; Hedrick, J. L. Polymer, 2006, 47, 4018; Bukhaltsev, E.; Frish, L.; Cohen, Y.; Vigalok, A. Org. Lett., 2005, 7, 5123; Ovitt, T. M.; Coates, G. W. J. Am. Chem. Soc., 2002, 124, 1316.

[3] Lee, J.; Kim, Y.; Do, Y. Inorg. Chem., 2007, 46, 7701; Umare, P. S.; Tembe, G. L.; Rao, K. V.; Satpathy, U. S.; Trivedi, B. J. Mol. Cat. A: Chem., 2007, 268, 235. Ejfler, J.; Kobylka, M.; Jerzykiewicz, L. B.; Sobota, P. J. Mol. Cat. A: Chem., 2006, 257, 105; Takashima, Y., Nakayama, Y.; Watanabe, K.; Itono, T.; Ueyama, N.; Nakamura, A.; Yasuda, H.; Harada, A. Macromolecules, 2002, 35, 7538.

[4] Frediani, M.; Sémeril, D.; Mariotti, A.; Rosi, L.; Frediani, P.; Rosi, L.; Matt, D.; Toupet, L. Macromol. Rapid Commun., 2008, 29, 1554.

[5] Janke, M.; Rudzevich, Y.; Molokanova, O.; Metzroth, T.; Mey, I.; Diezemann, G.; Marszalek, P. E.; Gauss, J.; Böhmer, V.; Janshoff, A. Nature Nanotech., 2009, 4, 225; Safi, S.; Asfari, Z.; Ehret-Sabatier, L.; Leroy, M.; Hagège, A. Bioconjugate Chem., 2006, 17, 1346; Motornaya, A. E.; Alimbarova, L. M.; Shokova, É. A.; Kovalev, V. V. Pharmaceut. Chem. J., 2006, 40, 68; Casnati, A.; Fabbi, M.; Pelizzi, N.; Pochini, A.; Sansone, F.; Ungano, R. Bioorg. Med. Chem. Lett., 1996; 6, 2699.

[6] Gedye, R.; Smith, F.; Westaway, K.; Ali, H.; Baldisera, L.; Laberge, L.; Rousell J. Tetrahedron Lett. 1986, 27, 279.

[7] Giguere, R. J.; Bray, T. L.; Duncan, S. M.; Majetich, G. Tetrahedron Lett. 1986, 27,4945

[8] Kappe, C. O.; Dallinger, D.; Murphee, S. S. in "Practical Microwave Synthesis for Organic Chemists", Wiley-VCH, Weinheim, 2008; Loupy A., "Microwaves in Organic Synthesis", Wiley-VCH, Weinheim, 2006.

[9] Hoogenboom, R.; Schubert, U. S. Macromol. Rapid Commun., 2007, 28, 368; Wiesbrock, F.; Hoogenboom, R.; Schubert, U. S. Macromol. Rapid Commun., 2004, 25, 1739 .

[10] Zhang, C.; Liao, L.; Gong, S.S. Macromol. Rapid Commun., 2007, 28, 422; Li, H.; Liao, L.; Liu, L. Macromol. Rapid Commun., 2007, 28, 411; Zhang, Y.M.; Wang, 
P.; Han, N.; Lei, H.F. Macromol. Rapid Commun., 2007, 28, 417; Jing, S.; Peng, W.; Tong, Z.; Baoxiu, Z. J. Appl. Polym. Sci., 2006, 100, 2244; Zhang, C.; Liao, L.; Liu, L. Macromol. Rapid Commun., 2004, 25, 1402.

[11] Frediani, M.; Sémeril, D.; Comucci, A.; Bettucci, L.; Frediani, P.; Rosi, L.; Matt, D.; Toupet, L.; Kaminsky, W. Macromol. Chem. Phys., 2007, 208, 938.

[12] Just, U.; Weidner, S.; Kilz, P.; Hofe, T. Int. J. Polym. Anal. Char., 2005, 10, 225.

[13] Di Lorenzo, M. L. Eur. Polym. J., 2005, 41, 569; Huang, J.; Lisowski, M. S.; Runt, J.; Hall, E. S.; Kean, R. T.; Buehler, N.; Lin, J. S. Macromolecules, 1998, 31, 2593.

[14] Kowalski, A.; Libiszowski, J.; Duda, A.; Penczek, S. Macromolecules, 2000, 33, 1964; Thakur K. A. M., Kean R. T., Hall E. S., Doscotch M. A., Munson E. J. Anal. Chem., 1997, 69, 4303; Zell, M. T.; Padden, B. E.; Paterick, A. J.; Hillmyer, M. A.; Kean, R. T.; Thakur, K. A. M.; Munson, E. J. J. Am. Chem. Soc., 1998, 120, 12672; Thakur, K. A. M.; Kean, R. T.; Hall, E. S.; Kolstad, J. J.; Lindgren, T. A.; Doscotch, M. A.; Siepmann, J. I.; Munson, E. J. Macromolecules, 1997, 30, 2422; Espartero, J. L.; Rashkov, I.; Li, S. M.; Manolova, N.; Vert, M. Macromolecules, 1996, 29, 3535.

[15] Montaudo, G.; Lattimer, R. P. "Mass Spectrometry of Polymers", CRC Press, Boca Raton, FL., 2002; Montaudo, G.; Montaudo; M. S.; Puglisi, C.; Samperi, F.; Spassky, N.; Le Borgne, A.; Wisniewski, M. Macromolecules, 1996, $29,6461$. [16] Mathew, A. P.; Oksman, K.; Sain M. J. Appl. Polym. Sci., 2006, 101, 300. 